\title{
IMPLIKASI HUKUM PERBANDINGAN KONSEP CO WORKING SPACE DENGAN PERKANTORAN DAN PERINDUSTRIAN BAGI PELAKU USAHA RINTISAN DI INDONESIA
}

\author{
Cita Yustisia Serfiyani \\ Fakultas Hukum, Universitas Wijaya Kusuma Surabaya \\ e-mail:nonacita@gmail.com
}

\begin{abstract}
ABSTRAK
Co working space merupakan inovasi terbaru bagi pelaku usaha di seluruh dunia termasuk Indonesia dalam menyiasati tingginya harga properti khususnya tempat kerja. Meskipun sama-sama berfungsi sebagai tempat kerja, gedung atau bangunan co working space tidak lantas dapat disamakan dengan gedung perkantoran dan perindustrian apalagi tempat hunian sehingga regulasi yang dirumuskan untuk mengatur co working space sepatutnya berbeda. Ijin pendirian bangunan yang dimanfaatkan sebagai co working space harus disesuaikan pula dengan pengaturan zonasi yang berbeda di setiap daerah karena belum adanya payung hukum di tingkat pusat. Di samping itu, hubungan hukum antara pemilik dan pengguna co working space tergantung dari jenis perjanjian hukum yang diberlakukan. Kesimpulan dari penelitian dengan metode yuridis normatif ini adalah bahwa dari perbandingan konsep co working space dengan konsep perkantoran dan perindustrian tersebut dapat dirumuskan karakteristik co working space serta implikasi hukum yang terjadi sehingga perlu diprioritaskan penyusunan regulasi yang mengatur $c o$ working space secara spesifik.
\end{abstract}

Kata Kunci: co working space; co sharing space; pelaku usaha rintisan

\begin{abstract}
Co working space is the latest innovation for businesses around the world including Indonesia to dealing with high property prices, especially for workplace. Although both function as workplaces, co working space cannot be equated with office and industrial building especially residential so the regulations should be different. Building permits used as co-working spaces must also be adjusted to different zoning arrangements in each region because there is no legal regulation at the national level. In addition, legal relationship between the owner and the co-working space user depends on the type of legal agreement that is enforced. The conclusion of the research with this normative juridical method is that from the comparison of the concept of co-working space with the concepts of office and industry, the characteristics of co-working space can be formulated along with the legal implications, so that specific co-working space regulations needs to be prioritized.
\end{abstract}

Keywords: co working space; co sharing space, start-up.

\section{PENDAHULUAN}

Perusahaan rintisan merupakan konsep baru dalam berwirausaha, khususnya wirausaha bidang ekonomi digital dan ekonomi kreatif. Peningkatan jumlah perusahaan rintisan, ketatnya persaingan dan jenis tantangan yang dihadapi oleh pelaku usaha dari tahun ke tahun seringkali berkembang lebih cepat dari lahirnya aturan-aturan baru yang dapat memberikan kepastian hukum. Pelaku usaha rintisan rencananya akan diatur dalam RUU Kewirausahaan walaupun dalam RUU Kewirausahaan terkait tidak ditemukan 
definisi khusus mengenai pelaku usaha rintisan dan cenderung dipersamakan dengan Wirausaha Pemula yang berada di level UMKM (Usaha Mikro, Kecil dan Menengah) di Indonesia. Berdasarkan Daftar Inventarisasi Masalah RUU Kewirausahaan Nasional Pasal 1 angka 1 disebutkan bahwa Wirausaha Pemula adalah wirausaha atau wirausaha sosial yang memulai kegiatan berwirausaha dalam jangka waktu kurang dari empat puluh dua bulan sejak terdaftar dan atau terdata di lembaga perizinan usaha.

Rumusan ini tidak sepenuhnya keliru mengingat pelaku usaha rintisan memang berhubungan dengan pelaku usaha pemula yang skala permodalannya masih rendah layaknya UMKM. Namun yang menjadi faktor pembeda antara pelaku usaha rintisan dengan UMKM pada umumnya yang dimaksud dalam istilah wirausaha pemula tersebut adalah adanya penekanan pada faktor inovasi dan pemanfaatan teknologi pada perusahaan rintisan yang mampu menyebabkan disrupsi pada aspek-aspek kehidupan. Faktor inilah yang tidak dimiliki oleh Wirausaha Pemula dalam konteks UMKM pada umumnya.

Menurut Mathias Klang, disrupsi khususnya disrupsi teknologi terjadi secara terus menerus bahkan tanpa disadari oleh masyarakat dan terjadi secara tidak menyenangkan karena dampak yang ditimbulkan. ${ }^{1}$ Cowan Schwartz mengungkapkan bahwa disrupsi teknologi dapat dipandang sebagai teknologi baru yang tidak sekedar menggantikan teknologi lama namun juga menggantikan tatanan sosial terkait yang menyebabkan manusia terpaksa beradaptasi terhadap perubahan tersebut. ${ }^{2}$ Hukum mengalami hambatan dalam merespons terjadinya disrupsi tersebut. ${ }^{3}$

Minimnya modal dan efisiensi tenaga kerja yang dialami oleh para pelaku usaha rintisan menyebabkan mereka harus lebih kreatif dalam melakukan kegiatan bisnis di tahap awal pendirian. Mengenai efisiensi jumlah tenaga kerja yang dibutuhkan dalam usaha rintisan kini sangat dimungkinkan terjadi berkat bantuan teknologi. Sementara itu, minimnya biaya

\footnotetext{
${ }^{1}$ Mathias Klang. (2006). Disruptive Technology: Effect of Technology Regulation on Democracy. Gotenborg: Gotenborg University, h. 9.

${ }^{2}$ ibid.

3 Muhammad Reza Winata, et.al. (2019). "Rekoneksi Hukum dan Disrupsi Teknologi Melalui Tafsir Konstitusional Mendukung Pembangunan Ekonomi Berkelanjutan". Jurnal Legislasi Indonesia. Volume 16 Nomor 4, h. 458-476.
}

salah satunya dapat diatasi dengan inovasi produk barang/jasa yang akan dihasilkan sehingga dapat menarik minat investor sejak awal. Kekurangan biaya tidak dapat diselesaikan secara pasif dengan menunggu bantuan permodalan dari lembaga keuangan ataupun pemerintah saja. Pelaku usaha rintisan cenderung aktif mencari investor secara swadaya sembari harus menekan biaya produksi seefisien mungkin.

Sektor pengeluaran yang menyerap biaya besar salah satunya adalah tempat kerja. Pelaku usaha UMKM yang bergerak di bidang jual beli makanan misalnya, memerlukan rombong, kedai atau ruko untuk dapat melakukan kegiatan bisnisnya. Begitu pula pelaku usaha UMKM untuk jenis produk barang dan jasa lain yang membutuhkan tempat fisik untuk tempat produksi dan berjualan sekalipun aktifitas penjualan dilakukan via daring sekalipun. Hal ini dialami pula oleh pelaku usaha rintisan. Kebutuhan vital ini terkendala oleh tingginya harga sewa dan harga beli properti sebagai tempat mengawali kegiatan bisnis. Jumlah pelaku usaha rintisan di Indonesia meningkat tiap tahunnya sehingga menyebabkan kebutuhan pelaku usaha rintisan terhadap tempat kerja pun meningkat, sementara itu menyelenggarakan kegiatan bisnis di rumah lambat laun tidak lagi dipandang sejalan dengan citra bisnis yang baik bagi setiap perusahaan. Masyarakat Industri Kreatif Teknologi Informasi dan Komunikasi Indonesia (MIKTI) mencatat jumlah perusahaan rintisan di Indonesia pada 2018 mencapai 992 perusahaan rintisan sesuai data yang tertera di situs resmi Badan Ekonomi Kreatif (BEKRAF), yang kini telah tergabung ke dalam Kementerian Pariwisata dan Ekonomi Kreatif. ${ }^{4}$ Jumlah itu belum termasuk dengan perusahaan rintisan yang baru berdiri atau belum terlacak saat riset dilakukan, karena berdasarkan versi dari lembaga pemeringkat swasta "StartUpRanking" yang mengelola situs pemeringkat khusus startup www.startupranking.com, Indonesia berada di posisi lima besar dunia. ${ }^{5}$

Menyikapi kebutuhan ini, mulailah muncul ide dari pemilik properti untuk menyewakan bagian

${ }^{4}$ MIKTI (Indonesia Digital Creative Industry Society). (2019). Mapping and Database Startup Indonesia 2018. Jakarta: Badan Ekonomi Kreatif.

5 Situs Resmi “StartUpRanking”, https://www. startupranking.com/countries, diakses tanggal 2 Februari 2020. 
terkecil dari rumahnya yakni "Ruang" bagi pelaku usaha. Pola penyewaan ruang ini lahir secara legal pada tahun 2005 di negara Amerika Serikat tepatnya di San Fransisco bernama "The Spiral Muse" walaupun saat itu belum lahir istilah co working space, hanya sebatas dikenal dengan istilah penyewaan ruang. Hanya dalam jangka waktu sekian tahun, jumlah $c o$ working space di seluruh dunia meningkat secara signifikan, yakni dari di bawah 100 pada Oktober 2007 menjadi 2.500 di akhir tahun $2013 .^{7}$

Konsep co working space yang berlaku saat ini yakni semua pekerja memiliki posisi setara, tanpa hierarki dan egaliter. Penggunaan ruang di $c o$ working space dapat berupa ruang/kamar/bilik/meja untuk setiap satu nama orang atau pelaku usaha yang terikat perjanjian dengan pemilik co working space yang sekaligus berperan sebagai pengelola gedung. Tidak ada batasan tentang jenis usaha apa yang boleh dan tidak boleh menggunakan tempat di co working space. Walaupun secara umum, usaha berbasis teknologi dan industri kreatif merupakan sektor usaha yang paling banyak menggunakan layanan ini. Apalagi, bisnis rintisan merupakan jenis bisnis terbaru di era ekonomi kreatif yang sedang popular saat ini walaupun belum dipayungi oleh aturan hukum yang spesifik dalam bentuk undang-undang.

Co working space di Indonesia memiliki perbedaan dengan gedung perkantoran maupun bangunan seperti gudang yang berada di area industri. Hubungan hukum antara para pihak pun sangat tergantung dari jenis perjanjian yang digunakan untuk mengikat pengguna dengan pemilik co working space.

\section{PERUMUSAN MASALAH}

Karakteristik co working space serta implikasi hukum yang dapat ditimbulkan.

\section{METODE PENELITIAN}

Penelitian hukum ini merupakan penelitian normatif dengan pendekatan perundang-undangan

\footnotetext{
${ }^{6}$ Minou Weijs-Perree, et.al., “Analysing User Preferences for Co Working Space Characteristics", Journal Building Research \& Information, Volume 47, 2019, h. 534-548.

${ }^{7}$ Bruno Moriset, "Building New Places of the Creative Economy. The Rise of Co Working Spaces", Prosiding, dipresentasikan pada 2nd Geography of Innovation International Conference 2014, Utrecht University, Netherland, h. 19.
}

(statute approach) dan pendekatan konsep (conceptual approach).

\section{PEMBAHASAN \\ Karakteristik Co Working Space}

Co Working Space merupakan konsep terbaru dalam pemanfaatan ruang kerja yang telah diterapkan di Indonesia berdasarkan hasil adaptasi dari negara lain yang telah mendahului seperti Jerman sebagai negara pionir lahirnya co working space dan Amerika Serikat dan Amerika sebagai negara dengan jumlah co working space terbanyak di dunia. ${ }^{8}$

Co working space di Indonesia pertama kali diterapkan di Bandung dengan nama "HACKERSPACE" sejak tahun 2010, sepuluh tahun berselang konsep ini telah diadopsi oleh kota-kota besar lain seperti Surabaya dan Jakarta. Jumlah bangunan atau gedung co working space tersebar di berbagai titik lokasi dan tiap bangunan dapat digunakan oleh pengguna yang berjumlah lebih dari satu bahkan sangat banyak. Walaupun hingga saat ini co working space belum diatur dalam regulasi di tingkat nasional sehingga terminologi hukum $c o$ working space belum dapat ditemukan di Indonesia.

Gambar 1. Peta persebaran Lokasi

Co Working Space di Seluruh Indonesia9

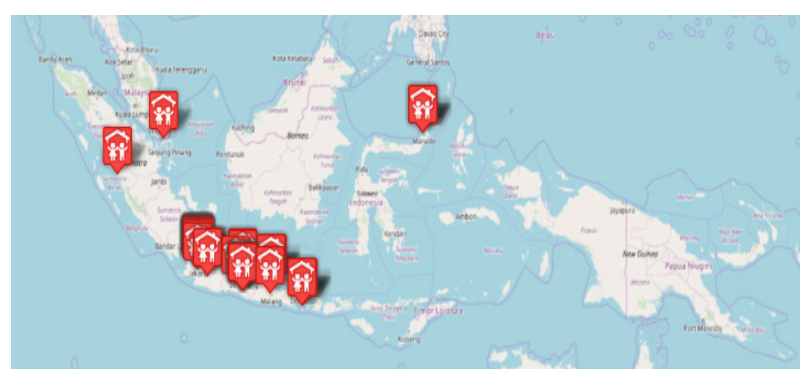

Pengguna co working space utamanya adalah pekerja sektor informal termasuk pelaku usaha kreatif dan perusahaan rintisan. ${ }^{10}$ Berdasarkan data

\footnotetext{
${ }^{8}$ Berdasarkan data oleh E. Mazareanu dari lembaga "Statista" yakni lembaga survei, riset dan analisis di skala internasional dengan outpot data statistik, telah diunggah di situs resmi Statista https:/www.statista.com/statistics/797546/ number-of-coworking-spaces-us/.

${ }^{9}$ Data diperoleh dari Komunitas Co Working Indonesia melalui situs resmi coworking.id, diakses tanggal 25 Februari 2020.

${ }^{10}$ Minou Weijs-Perree, op.cit.
} 
dari Badan Pusat Statistik pada awal tahun 2019, ${ }^{11}$ masyarakat Indonesia dari berbagai kelompok umur yang bekerja di sektor informal (baik informal pertanian maupun non pertanian) mengalami peningkatan, termasuk di dalamnya pekerjaan sebagai wirausaha dan terkenal pula istilah freelancer.

Perusahaan rintisan sebagai pengguna potensial co working space tidak wajib berbadan hukum karena mereka dapat mengawali usaha tanpa memprioritaskan legalitas badan usahanya. Perusahaan rintisan bahkan dapat didirikan dan dijalankan seorang diri dalam bentuk usaha perseorangan di tahap awal. Adapun pendirian usaha perseorangan tidak diatur dalam KUHD dan hanya didirikan oleh satu orang. Makna usaha perseorangan disini sama halnya dengan pedagang bakso, pedagang sayur di pasar, pemilik toko dan sejenisnya yang melakukan kegiatan usaha sendirian dan bebas tanpa mendaftarkannya sebagai PO ataupun UD ke Dinas Perindustrian dan Perdagangan. Di samping itu, perusahaan rintisan dapat berbentuk badan usaha non badan hukum seperti persekutuan komanditer (CV), Perusahaan Perorangan (PO), Usaha Dagang (UD) bahkan dapat berupa usaha perseorangan yang hanya dijalankan oleh seorang pelaku saja. Hal ini diperbolehkan bagi perusahaan rintisan apalagi batasan kriteria dan prasyarat dari perusahaan rintisan juga belum diatur secara sah dalam RUU Kewirausahaan dan masih disamakan dengan Wirausaha Pemula.

Keberadaan co working space sebenarnya merupakan perwujudan asas gotong royong yang terpatri di falsafah hidup bangsa Indonesia dan terjewantahkan dalam konsep ekonomi (sharing economy) dimana suatu aset, proyek, produk, jasa dimanfaatkan untuk sebanyak mungkin orang dalam waktu bersamaan dan mengurangi kepemilikan tunggal agar bermanfaat sebesar-besarnya bagi masyarakat atau (collaborative consumption) ${ }^{12}$.

Co working space merupakan salah satu contoh dari penerapan sharing economy tersebut dalam hal

11 Data Badan Pusat Statistika, dapat diunduh pula di situs resmi Badan Pusat Statistika, https://www.bps. go.id/dynamictable/2018/05/16/1309/proporsi-lapangankerja-informal-sektor-non-pertanian-menurut-kelompokumur-2015---2018.html.

12 Juho Hamari, et.al., "The Sharing Economy, Why People Participate in Collaborative Consumption", Journal of the Association for Information Science and Technology, Volume 67, Issue 9, September 2016, h. 2047-2059. berbagi ruang. Co working space adalah bagian dari konsep co sharing spaces secara global yang terdiri dari co living space (hunian), co working space (tempat kerja), co warehouse space (penyimpanan dan gudang), dan lain-lain. Secara harfiah, co working space bisa diartikan sebagai tempat bekerja bagi orang-orang dari berbagai institusi atau organisasi yang tidak mengenal dan tidak berasal dari latar belakang yang sama. Spinuzzi menyebutnya sebagai "working alone together"13 (bekerja sendiri secara bersama-bersama).

Orang-orang tersebut sengaja berbagi tempat kerja bukan hanya untuk alasan efisiensi biaya dan tempat namun juga untuk memperluas jejaring dengan sesama pelaku usaha. Menurut Clifton, ${ }^{14}$ pendorong utama dalam kemajuan ekonomi digital adalah rekan kerja yang dapat bekerjasama, fleksibel, berkomunikasi dengan baik dan lancar serta saling berkontribusi.

Inilah mengapa pengguna sebuah gedung co working space pada umumnya sama-sama berasal dari sektor industri kreatif yang dapat saling mendukung karier satu sama lain. Pemilik sekaligus pengelola co working space tidak sekedar menyediakan tempat namun juga harus mampu memfasilitasi para penggunanya agar nyaman berinteraksi dengan sesama pengguna lain, akses internet yang cepat, listrik, air bersih, bahkan arsitektur dan desain interior menjadi komponen penting yang tidak hanya memberikan keindahan pada bangunan namun juga mendukung citra sebuah co working space ke depannya.

Hubungan hukum terjadi antara pemilik dan pengelola gedung dengan pengguna dalam bentuk perjanjian sewa. Objek sewa adalah "ruang" baik berukuran satu meja atau lebih, satu bilik, satu ruangan tanpa sekat, satu ruangan tertutup yang meliputi pula hak bagi penyewa untuk memanfaatkan seluruh fasilitas yang disediakan di dalam gedung secara bersama (komunal).

Relasi antara sesama penyewa sangat fleksibel dan tentunya tanpa hierarki. Pengguna co working space bebas datang kapanpun ke gedung co working

${ }^{13}$ Clay Spinuzzi, "Working Alone Together: Co Working as Emergent Collaborative Activity", Journal of Business and Technical Communication, Volume 26, Issue 4, 2012, h. 399-441.

${ }^{14}$ Nick Clifton, et.al., "Coworking in the Digital Economy: Context, Motivations and Outcomes, Futures Journal, July 2019. 
space tanpa terikat hari kerja dan jam kerja, berbeda dengan perkantoran dan perindustrian yang lebih kaku pada jadwal kerja. Kebebasan kerja inilah yang harus mampu difasilitasi oleh pengelola misalnya dalam hal menampung surat-surat masuk serta menjaga properti pengguna. Pemilik dan pengelola juga harus mampu memberikan atmosfir yang nyaman untuk bersosialisasi namun tetap mendukung pengguna fokus dalam bekerja karena privasi tetap harus terjaga meskipun pengguna bekerja dalam tempat yang berkonsep terbuka (open space). Perbedaan habit dan cara kerja tersebut menjadi alasan penting bagi pengguna co working space untuk tidak membutuhkan ruang yang terlampau besar dalam menunjang kinerjanya, mereka tidak akan merasa cocok jika harus menyewa tempat di gedung perkantoran, perindustrian dan ruko. Orang yang bekerja di coworking space merasa lebih bahagia daripada yang bekerja di tempat lain, dapat memperluas networking, lebih fokus daripada bekerja di kafe dan membuat mereka memiliki bahagia dalam bekerja karena dapat memiliki kontrol lebih terhadap pekerjannya. ${ }^{15}$

Saat seorang pelaku usaha rintisan melakukan aktifitas pekerjaannya di co working space, hal itu dapat memberikan nilai tambah bagi usahanya misal dalam hal pemberian alamat untuk korespondensi dengan klien dan untuk perusahaan rintisan yang ingin mendirikan badan usaha berbadan hukum seperti PT tidak dapat menggunakan alamat rumahnya sehingga digunakanlah alamat gedung co working space. Walaupun tiap Kota atau Kabupaten memiliki pengaturan yang berbeda tentang boleh atau tidaknya menggunakan alamat co working space yang sama untuk banyak PT yang berbeda.

Faktor utama pembeda co working space dengan perkantoran dan perindustrian adalah tujuan pendirian dan pemanfaatan gedung/bangunan yang berdasarkan pada konsep sharing economy sehingga timbullah ide untuk menggunakan satu ruang secara komunal serta menggeser makna ruang kerja yang sebelumnya terbatas pada satu ruangan, satu lantai, satu gedung (pada konsep perkantoran) atau satu pabrik dan satu kantor (pada konsep perindustrian) menjadi lebih sederhana yakni per satuan meja, bilik dan ruangan sedangkan fasilitas gedung lainnya digunakan bersama sehingga memaksimalkan penggunaan ruang (space) dan menekan biaya. Berikut ini adalah beberapa faktor pembanding lainnya agar lebih memperjelas perbandingan antara konsep co working space dengan konsep perkantoran dan perindustrian yang disajikan dalam bentuk tabel:

Tabel 1. Perbandingan antara Co Working Space dengan Perkantoran \& Perindustrian

\begin{tabular}{|c|c|c|}
\hline Faktor & Co Working Space & $\begin{array}{c}\text { Perkantoran \& } \\
\text { Perindustrian }\end{array}$ \\
\hline $\begin{array}{l}\text { Tujuan } \\
\text { pendirian }\end{array}$ & $\begin{array}{l}\text { Memaksimalkan } \\
\text { pengunaan ruang } \\
\text { untuk pelaku usaha } \\
\text { rintisan, UMKM dan } \\
\text { pelaku industri kreatif } \\
\text { dengan menerapkan } \\
\text { konsep sharing } \\
\text { economy. }\end{array}$ & $\begin{array}{l}\text { Diutamakan untuk } \\
\text { dimanfaatkan } \\
\text { oleh pelaku usaha } \\
\text { berbadan hukum } \\
\text { maupun non badan } \\
\text { hukum di bidang } \\
\text { usaha apapun. }\end{array}$ \\
\hline $\begin{array}{l}\text { Pemanfaatan } \\
\text { bangunan }\end{array}$ & $\begin{array}{l}\text { Penggunaan ruang } \\
\text { diinterpretasikan } \\
\text { dengan per satuan } \\
\text { meja/bilik/ruang untuk } \\
\text { setiap pelaku usaha. }\end{array}$ & $\begin{array}{l}\text { Penggunaan ruang } \\
\text { atas suatu gedung } \\
\text { dapat dimanfaatkan } \\
\text { seluruhnya atau } \\
\text { pun per lantai/unit/ } \\
\text { ruangan. }\end{array}$ \\
\hline $\begin{array}{l}\text { Status } \\
\text { kepemilikan } \\
\text { bangunan }\end{array}$ & $\begin{array}{l}\text { Bangunan hanya dapat } \\
\text { dimiliki oleh pemilik } \\
\text { co working space, } \\
\text { tidak dapat dimiliki } \\
\text { oleh pengguna. }\end{array}$ & $\begin{array}{l}\text { Bangunan dapat } \\
\text { dimiliki oleh pelaku } \\
\text { usaha. }\end{array}$ \\
\hline $\begin{array}{l}\text { Hubungan } \\
\text { hukum }\end{array}$ & $\begin{array}{l}\text { Hubungan hukum } \\
\text { para pihak lahir } \\
\text { dari perjanjian sewa } \\
\text { menyewa. }\end{array}$ & $\begin{array}{l}\text { Hubungan hukum } \\
\text { tergantung dari cara } \\
\text { perolehan bangunan } \\
\text { yang dapat terjadi } \\
\text { karena jual beli, sewa } \\
\text { menyewa dan hibah. }\end{array}$ \\
\hline $\begin{array}{l}\text { Dasar hukum } \\
\text { pendirian } \\
\text { bangunan }\end{array}$ & $\begin{array}{l}\text { Belum ada regulasi } \\
\text { khusus dalam } \\
\text { bentuk undang- } \\
\text { undang tersendiri } \\
\text { yang mengatur } \\
\text { perlindungan hukum } \\
\text { terhadap co working } \\
\text { space. }\end{array}$ & $\begin{array}{l}\text { Perlindungan } \\
\text { hukum mengacu } \\
\text { pada peraturan di } \\
\text { bidang Hukum Tata } \\
\text { Ruang untuk zonasi } \\
\text { pendirian gedung } \\
\text { perkantoran, gudang } \\
\text { dan area perindustrian } \\
\text { untuk perijinan } \\
\text { mendirikan bangunan. }\end{array}$ \\
\hline $\begin{array}{l}\text { Biaya } \\
\text { pemanfataan } \\
\text { bangunan }\end{array}$ & $\begin{array}{l}\text { Biaya sewa ruang di } \\
\text { co working space lebih } \\
\text { efisien karena ukuran } \\
\text { ruang yang lebih kecil. }\end{array}$ & $\begin{array}{l}\text { Biaya relatif lebih } \\
\text { tinggi tergantung dari } \\
\text { ukuran luas properti. }\end{array}$ \\
\hline
\end{tabular}

${ }^{15}$ Gretchen Spreitzer, et.al., "Why People Thrive in Co Working Space?", Harvard Business Review, September 2015, h. 28-30. 


\section{Implikasi Hukum terhadap Karakteristik Co Working Space}

Implikasi hukum dari pengkarakteristikan $c o$ working space yang ternyata berbeda dengan gedung perkantoran, gudang dan area perindustrian seperti pembahasan di sub bab sebelumnya akan berdampak pada pengurusan ijin usaha atau pendaftaran usaha bagi para pelaku usaha rintisan yang menyewa atau menggunakan co working space dengan satu alamat yang sama. Pengurusan seperangkat ijin usaha seperti Tanda Daftar Perusahaan (TDP) dan Surat Izin Usaha Perdagangan (SIUP) beberapa badan usaha dengan nama berbeda, jenis usaha berbeda dan pemilik yang berbeda tidak dapat didaftarkan atas satu alamat yang sama persis. Urusan korespondensi para pelaku usaha juga dapat berpotensi mengalami kesulitan karena banyaknya pengguna dengan perbedaan usaha dan kepentingan dialamatkan pada satu alamat yang sama persis.

Hal-hal tersebut masih menjadi kendala dalam penggunaan co working space oleh pelaku usaha rintisan karena belum adanya payung hukum dan patut diingat pula bahwa kecenderungan yang terjadi adalah sebuah terobosan baru di Indonesia seringkali mendahului peraturan hukum, atau dengan kata lain hukum Indonesia masih bersifat responsif, belum mampu menjadi hukum yang progresif. Adapun dasar hukum yang dapat digunakan saat ini dalam memberikan payung hukum bagi pemanfataan bangunan co working space untuk pelaku usaha rintisan adalah asas kebebasan berkontrak yang terkandung dalam Pasal 1338 ayat (1) KUHPerdata dan pasal-pasal dalam Buku III KUHPerdata dalam hal perbuatan hukum pinjam meminjam dan sewa menyewa.

Bangunan co working space wajib memiliki Ijin Mendirikan Bangunan (IMB) sesuai UU Nomor 28 Tahun 2002 tentang Bangunan Gedung serta membayar Pajak Bumi dan Bangunan (PBB). Mengenai ijin pendirian awal bangunan yang akan digunakan sebagai co working space tersebut masih dianggap masuk ke dalam kategori gedung perkantoran, ruko, rumah tempat tinggal atau bahkan bergabung dengan kafe walaupun setelah bangunan berdiri ternyata peruntukannya tidak sesuai ijin semula. Padahal, IMB bukan sekedar surat bukti ijin namun juga mengandung janji bahwa pemilik bangunan akan mendirikan dan memanfaatkan bangunannya sesuai fungsi bangunan dan rencana teknis yang telah disetujui oleh Pemerintah Daerah setempat.

Hal tersebut dapat terjadi lantaran belum adanya kategori co working space secara spesifik dalam kepentingan pengajuan ijin pendirian bangunan. Padahal sebagaimana telah dijelaskan di sub bab sebelumnya bahwa co working space tidak dapat disamakan dengan kantor dan rumah tinggal. Ia memiliki kategorinya tersendiri. Menurut Peter Ross, ${ }^{16}$ co working space bukan kantor juga bukan pula rumah dan sengaja diciptakan sebagai alternatif dari tempat kerja "home-based" yang didukung dengan lingkungan kerja berkonsep "open space”. Co working space sebagai konsep terbaru tempat kerja telah mendisrupsi konsep lama dalam pengkategorian bangunan ke dalam perkantoran saja, atau rumah tinggal saja, ataupun tempat bisnis saja.

Pemilik dan pengelola co working space dapat berasal dari perorangan, perusahaan swasta hingga pemerintah. Pengguna co working space dapat berasal dari berbagai kalangan profesi dan tujuan tergantung tujuan pendirian tiap bangunan co working space yang ditetapkan oleh pemilik dan pengelola. Contohnya, co working space yang pertama kali ada di Indonesia yakni "HACKERSPACE" di Bandung yang dikelola oleh pihak swasta dan "KORIDOR" milik Pemerintah Kota Surabaya. HACKERSPACE tidak menetapkan biaya sewa dan hanya menerima dana dalam bentuk donasi yang akan digunakan kembali untuk kepentingan pengelolaan HACKERSPACE sehingga terjalin komunitas yang erat. Perjanjian yang berlaku di antara para pihak adalah perjanjian pinjam meminjam (tanpa biaya sewa) dan terjadi pula perbuatan hukum hibah berupa uang (donasi).

Di sisi lain, KORIDOR hanya dikhususkan untuk pelaku usaha individu di level UMKM dan perusahaan rintisan. Pelaku usaha yang telah memiliki badan usaha tidak diperbolehkan menggunakan tempat tersebut. Pembagian tempat sepenuhnya kebijakan Pemerintah Kota Surabaya dan tanpa biaya sehingga perjanjian penggunaan tempat antara pemilik dan pengguna berdasarkan pada perjanjian pinjam meminjam selayaknya yang diatur dalam Pasal 1754 KUHPerdata (dalam hal

\footnotetext{
${ }^{16}$ Peter Ross, et.al., "Neither Office Nor Home: Coworking as an Emerging Workplace Choice", Journal Employment Relation Record, Volume 11, Issue 1, 2015, h. 42-57.
} 
ini pinjam meminjam tempat/ruang) namun tanpa disertai biaya tambahan dalam kesepakatan antar kedua belah pihak. Dalam hal ini, kedua belah pihak mengesampingkan ketentuan Pasal 1266 dan 1267 KUHPerdata karena hubungan hukum di antara keduanya bukan lahir dari perjanjian sewa menyewa.

Sementara itu, co working space milik perusahaan swasta "SUBco" yang juga berlokasi di Surabaya tidak membatasi penggunanya merupakan pelaku usaha secara individu ataupun lebih dari satu orang, serta sudah berbadan hukum ataupun tidak berbadan hukum. Pemanfaatan tempat dikenakan biaya sewa dalam perjanjian sewa menyewa layaknya perjanjian sewa menyewa properti pada umumnya namun objek yang disewakan disini adalah "ruang" sebagai bagian dari properti.

Terhadap co working space yang menerapkan perjanjian sewa menyewa, ada yang menerapkan perjanjian dalam bentuk akta otentik dan akta di bawah tangan. Perjanjian sewa menyewa bermaterai dan dilakukan di hadapan notaris antara kedua belah pihak sehingga dapat tergolong sebagai akta otentik yang menjadi alat bukti yang cukup bagi kedua pihak untuk mendapatkan haknya, ${ }^{17}$ ada pula yang cukup mengikatnya dengan perjanjian sewa menyewa di bawah tangan.

Perjanjian sewa menyewa tetap mengikat para pihak dan meskipun seandainya terjadi bangunan tersebut dijual atau dialihkan saat masa sewa belum berakhir maka perjanjian sewa yang telah terjadi sebelumnya tidak putus sebelum durasi yang telah disepakati dalam poin perjanjian tersebut berakhir. ${ }^{18}$ Hal ini sesuai dengan Pasal 1576 KUHPerdata yang mengatur agar perjanjian jual beli tidak lantas membatalkan perjanjian sewa menyewa antar pengguna dan pemilik co working space tersebut. Terhadap perjanjian sewa di bawah tangan maka perjanjian tersebut memiliki kekuatan pembuktian selama seluruh pihak dalam perjanjian mengakui keabsahan akta tersebut, namun jika salah satu pihak tidak mengakui adanya akta tersebut, maka pihak

\footnotetext{
${ }^{17}$ Christin Sasauw, "Tinjauan Yuridis tentang Kekuatan Mengikat Suatu Akta Notaris", Lex Privatum, Volume 3, Nomor 1, 2015, h. 98-109.

18 Djaja S. Meliala. (2012). Penuntun Praktis Hukum Perjanjian Khusus: Jual Beli, Sewa Menyewa, Pinjam Meminjam. Bandung: Nuansa Aulia, h. 59.
}

lain wajib membuktikan bahwa perjanjian itu benar adanya. ${ }^{19}$

Terkait ijin pendirian co working space, cara pemerintah daerah masing-masing dalam mengatur hal tersebut berpedoman pada UU Nomor 26 Tahun 2007 tentang Penataan Ruang dan selanjutnya berpedoman pula kepada kebijakan Rencana Daerah Tata Ruang (RDTR) yang berbeda-beda antar daerah karena menjadi otonomi daerah masing-masing untuk menentukan. UU tersebut tidak mengenal konsep co working space sehingga Pemerintah Daerah pun dalam mengeluarkan Kebijakan RDTR rancu dalam mengkategorikan co working space ke dalam bentuk perkantoran sehingga masuk ke zona bisnis ataukah bentuk pergudangan dan perindustrian sehingga masuk ke zona industri ataukah tetap dibiarkan didirikan di sekitar lingkungan perumahan sehingga diijinkan berada di zona pemukiman.

Beberapa daerah di Indonesia, contohnya Provinsi DKI Jakarta, sudah mulai mencoba mengatur co working space namun dengan istilah lain yakni virtual office. Pengaturan co working space dapat diatur oleh Pemerintah Daerah terkait ijin pendirian bangunan co working space oleh pemilik dan pengelolaan bangunan co working space yang telah dituangkan di Peraturan Daerah DKI Jakarta Nomor 1 Tahun 2014 tentang Rencana Detail Tata Ruang dan Peraturan Zonasi serta pendaftaran ijin usaha kepada Pemerintahan Daerah terkait $c q$ Dinas Perindustrian dan Perdagangan. Pemerintah DKI Jakarta mengatur fungsi-fungsi ruang di Jakarta, contohnya kegiatan industri di wilayah Pulogadung tidak boleh didirikan rumah dan gedung co working space. Peraturan Daerah tersebut kemudian disusul dengan terbitnya Surat Edaran Kepala BPTSP DKI Jakarta No. 6 Tahun 2016 yang bermaksud memberi kemudahan bagi perusahaan rintisan di co working space atau virtual office untuk dapat menggunakan alamat $c o$ working space dalam kepentingan pengurusan ijin usaha seperti Surat Keterangan Domisili.

Permasalahannya adalah kantor Pelayanan Terpadu Satu Pintu (PTSP) di daerah lain di Indonesia, selain DKI Jakarta, juga baru dapat mengeluarkan izin jika domisili berada di zonasi usaha yakni perkantoran atau perindustrian sedangkan lokasi $c o$

${ }^{19}$ Richard Cisanto Palit. "Kekuatan Akta di Bawah Tangan sebagai Alat Bukti di Pengadilan", Lex Privatum, Volume 3, Nomor 2, 2015, h. 137-145. 
working space ini tersebar di berbagai macam zonasi termasuk zonasi pemukiman. Tiap Kota/Kabupaten memiliki pengaturan yang berbeda tergantung kebijakan Pemerintah Daerah setempat karena pengaturan co working space saat ini masih menjadi otonomi daerah masing-masing dan dipersamakan dengan gedung perkantoran tanpa mengindahkan karakteristik dari co working space itu sendiri.

Oleh sebab itu, diharapkan ke depannya aspekaspek tersebut dapat diatur secara tegas dalam peraturan perundang-undangan yang khusus mengatur co working space dengan memuat hakekat, karakteristik dan filosofi co working space sebagai inovasi baru tempat kerja yang berbeda dengan gedung perkantoran, gudang dan area perindustrian sehingga membawa implikasi hukum yang berbeda dan harus diatur secara khusus sehingga mampu memberikan perlindungan hukum bagi para pihak

\section{PENUTUP}

\section{Kesimpulan}

Co working space sebagai bagian dari co sharing space merupakan perwujudan dari konsep sharing economy. Co working space memiliki karakteristik hukum yang berbeda dengan gedung perkantoran dan perindustrian antara lain jika ditinjau dari segi tujuan pemanfaatan bangunan, status kepemilikan bangunan, pemanfaatan bangunan, hubungan hukum, dasar hukum pendirian bangunan dan biaya pemanfaatan bangunan. Hal ini akan membawa implikasi hukum yang berbeda, antara lain dalam hal perijinan usaha pelaku usaha pengguna co working space serta perijinan pendirian bangunan co working space oleh pemilik. Mengenai hubungan hukum para pihak tergantung dari jenis perjanjian yang mengikat keduanya yakni perjanjian pinjam meminjam ataukah perjanjian sewa menyewa.

\section{Rekomendasi}

Co working space ke depannya harus diatur di tingkat pusat dalam bentuk Undang-Undang yang secara spesifik mengatur hal tersebut. Perumusan Undang-Undang tersebut hendaknya disesuaikan dengan karakteristik co working space demi memberikan kepastian hukum bagi pemilik, pengelola dan pengguna serta mendukung kemajuan perusahaan rintisan di Indonesia.

\section{DAFTAR PUSTAKA \\ Peraturan Perundang-undangan:}

Kitab Undang-Undang Hukum Perdata.

Undang-Undang Nomor 28 Tahun 2002 tentang Bangunan Gedung.

Undang-Undang Nomor 26 Tahun 2007 tentang Penataan Ruang.

Peraturan Daerah DKI Jakarta Nomor 1 Tahun 2014 tentang Rencana Detail Tata Ruang dan Peraturan Zonasi.

Surat Edaran Kepala BPTSP DKI Jakarta No. 6 Tahun 2016

\section{Buku:}

Djaja S. Meliala. (2012). Penuntun Praktis Hukum Perjanjian Khusus: Jual Beli, Sewa Menyewa, Pinjam Meminjam, Bandung: Nuansa Aulia.

MIKTI (Indonesia Digital Creative Industry Society). (2019). Mapping and Database Startup Indonesia 2018. Jakarta: Badan Ekonomi Kreatif.

\section{Disertasi:}

Mathias Klang. (2006). "Disruptive Technology: Effect of Technology Regulation on Democracy". Disertasi. Gotenborg: Gotenborg University.

\section{Jurnal:}

Christin Sasauw. "Tinjauan Yuridis tentang Kekuatan Mengikat Suatu Akta Notaris". Lex Privatum. Volume 3, Nomor 1, 2015, h. 98-109.

Clay Spinuzzi. "Working Alone Together : Co Working as Emergent Collaborative Activity". Journal of Business and Technical Communication. Volume 26, Issue 4, 2012, h. 399-441.

Gretchen Spreitzer, et.al. "Why People Thrive in Co Working Space?". Harvard Business Review. September 2015, h. 28-30.

Juho Hamari, et.al. "The Sharing Economy, Why People Participate in Collaborative Consumption". Journal of the Association for Information Science and Technology. Volume 67, Issue 9, September 2016, h. 2047-2059.

Muhammad Reza Winata, et.al. "Rekoneksi Hukum dan Disrupsi Teknologi Melalui Tafsir Konstitusional Mendukung Pembangunan Ekonomi Berkelanjutan”. Jurnal Legislasi 
Indonesia. Volume 16, Nomor 4, 2019, h. 458476.

Minou Weijs-Perree, et.al. "Analysing User Preferences for Co Working Space Characteristics". Journal Building Research \& Information. Volume 47, 2019, h. 534-548.

Nick Clifton, et.al. "Coworking in the Digital Economy: Context, Motivations and Outcomes". Futures Journal. July 2019.

Peter Ross, et.al. "Neither Office Nor Home: Coworking as an Emerging Workplace Choice". Journal Employment Relation Record. Volume 11, Issue 1, 2015.

Richard Cisanto Palit. "Kekuatan Akta di Bawah Tangan sebagai Alat Bukti di Pengadilan". Lex Privatum. Volume 3, Nomor 2, 2015, h. 137-145.

\section{Prosiding:}

Bruno Moriset. "Building New Places of the Creative Economy. The Rise of Co Working Spaces". Prosiding dipresentasikan pada 2nd Geography of Innovation International Conference 2014. Netherland: Utrecht University.

\section{Website:}

Data Badan Pusat Statistika, dapat diunduh pula di situs resmi Badan Pusat Statistika, https:// www.bps.go.id/dynamictable/2018/05/16/1309/ proporsi-lapangan-kerja-informalsektor-non-pertanian-menurut-kelompokumur-2015---2018.html.

E. Mazareanu dari lembaga "Statista" yakni lembaga survei, riset dan analisis di skala internasional dengan outpot data statistik, telah diunggah di situs resmi Statista https://www.statista.com/ statistics/797546/number-of-coworking-spacesus/.

Komunitas Co Working Indonesia. coworking.id, diakses tanggal 25 Februari 2020.

Situs Resmi "StartUpRanking", https://www. startupranking.com/countries, diakses tanggal 2 Februari 2020. 